\title{
MONOTONICITY AND INEQUALITIES INVOLVING ZERO-BALANCED HYPERGEOMETRIC FUNCTION
}

\author{
MiaO-Kun Wang, Yu-Ming Chu And Wen ZHANG
}

Abstract. In the article, we present a monotonicity property involving the zero-balanced hypergeometric function $F(a, b ; a+b ; x)$ for all $a, b>0$, and establish several sharp inequalities for $F(a, b ; a+b ; x)$ in the first quadrant of $a b$-plane, which are the generalizations of the previously results.

Mathematics subject classification (2010): 33C05, 33E05.

Keywords and phrases: Gaussian hypergeometric function, generalized elliptic integral, monotonicity, inequality.

\section{REFERENCES}

[1] M. Abramowitz, I. A. Stegun, Handbook of Mathematical Functions with Formulas, Graphs and Mathematical Tables, Dover, New York, 1965.

[2] M. Adil Khan, Y.-M. ChU, A. Kashuri, R. Liko, Conformable fractional integrals versions of Hermite-Hadamard inequalities and their generalizations, J. Funct. Spaces 2018 (2018), Article ID 6928130, 9 pages.

[3] M. Adil Khan, Y.-M. Chu, A. Kashuri, R. Liko, Hermite-Hadamard type fractional integral inequalities for $M T_{(r ; g, m, \varphi)}$-preinvex functions, J. Comput. Anal. Appl. 28, (8) (2019), 1487-1503.

[4] M. Adil Khan, Y.-M. ChU, T. U. Khan, J. Khan, Some new inequalities of Hermite-Hadamard type for s-convex functions with applications, Open Math. 15 (2017), 1414-1430.

[5] H. AlzER, Sharp inequalities for the complete elliptic integral of the first kind, Math. Proc. Cambridge Philos. Soc. 24, 2 (1998), 309-314.

[6] H. Alzer, S.-L. QIU, Monotonicity theorems and inequalities for the complete elliptic integrals, J. Comput. Appl. Math. 172, 2 (2004), 289-312.

[7] G. D. Anderson, S.-L. QiU, M. K. Vamanamurthy, Elliptic integral inequalities, with applications, Constr. Approx. 14, 2 (1998), 195-207.

[8] G. D. Anderson, S.-L. Qiu, M. K. Vamanamurthy, M. Vuorinen, Generalized elliptic integrals and modular equations, Pacific J. Math. 192, 1 (2000), 1-37.

[9] G. D. Anderson, M. K. Vamanamurthy, M. Vuorinen, Conformal Invariants, Inequalities, and Quasiconformal Maps, John Wiley \& Sons, New York, 1997.

[10] G. D. Anderson, M. K. Vamanamurthy, M. Vuorinen, Topics in special functions, In: Papers on Analysis: A volume dedicated to Olli Martio on the occasion of his 60th birthday, Report Univ. Jyväskylä, 83 (2001), 5-26.

[11] R. Balasubramanian, S. Naik, S. Ponnus Amy, M. Vuorinen, Elliott's identity and hypergeometric functions, J. Math. Anal. Appl. 271, 1 (2002), 232-256.

[12] B. C. BERndT, Ramanujan's Notebooks II, Springer-Verlag, New York, 1989.

[13] B. A. BhaYo, M. VuORinen, On generalized complete elliptic integrals and modular functions, Proc. Edinb. Math. Soc. (2) 55, 3 (2012), 591-611.

[14] Y.-M. ChU, Y.-H. Haо, X.-G. LiU, Global weak solutions to a general liquid crystals system, Discrete Contin. Dyn. Syst. 33, 7 (2013), 2681-2710.

[15] Y.-M. CHU, Y.-M. LI, W.-F. XIA, X.-H. ZHANG, Best possible inequalities for the harmonic mean of error function, J. Inequal. Appl. 2014 (2014), Article 525, 9 pages. 
[16] Y.-M. ChU, Y.-F. QIU, M.-K. WANG, Hölder mean inequalities for the complete elliptic integrals, Integral Transforms Spec. Funct. 23, 7 (2012), 521-527.

[17] Y.-M. ChU, Y.-F. QIU, M.-K. WANG, Y.-F. QIU, On Alzer and Qiu's conjecture for complete elliptic integral and inverse hyperbolic tangent function, Abstr. Appl. Anal. 2011 (2011), Article ID 697547, 7 pages.

[18] Y.-M. ChU, M.-K. WANG, Optimal inequalities between harmonic, geometric, logarithmic, and arithmetic-geometric means, J. Appl. Math. 2011 (2011), Article ID 618929, 9 pages.

[19] Y.-M. ChU, M.-K. WANG, Optimal Lehmer mean bounds for the Toader mean, Results Math. 61, 3-4 (2012), 223-229.

[20] Y.-M. CHU, M.-K. WANG, Inequalities between arithmetic-geometric, Gini, and Toader means, Abstr. Appl. Anal. 2012 (2012), Article ID 830585, 11 pages.

[21] Y.-M. ChU, M.-K. WANG, Y.-P. JIANG, S.-L. QIU, Concavity of the complete elliptic integrals of the second kind with respect to Höler means, J. Math. Anal. Appl. 395, 2 (2012), 637-642.

[22] Y.-M. CHU, M.-K. WANG, X.-Y. MA, Sharp bounds for Toader mean in terms of contraharmonic mean with applications, J. Math. Inequal. 7, 2 (2013), 161-166.

[23] Y.-M. ChU, M.-K. WANG AND S.-L. QIU, Optimal combinations bounds of root-square and arithmetic means for Toader mean, Proc. Indian Acad. Sci. Math. Sci. 122, (1) (2012), 41-51.

[24] Y.-M. ChU, M.-K. WANG, S.-L. QIU, Y.-P. JIANG, Bounds for complete elliptic integrals of the second kind with applications, Comput. Math. Appl. 63, 7 (2012), 1177-1184.

[25] Y.-M. ChU, M.-K. WANG, Y.-F. QIU, X.-Y. MA, Sharp two parameter bounds for the logarithmic mean and the arithmetic-geometric mean of Gauss, J. Math. Inequal. 7, 3 (2013), 349-355.

[26] Y.-M. ChU, M.-K. WANG, S.-L. QIU, Y.-F. QIU, Sharp generalized Seiffert mean bounds for Toader mean, Abstr. Appl. Anal. 2011 (2011), Article ID 605259, 8 pages.

[27] Y.-M. ChU, G.-D. WANG, X.-H. ZhANG, Schur convexity and Hadamard's inequality, Math. Inequal. Appl. 13, 4 (2010), 725-731.

[28] Y.-M. ChU, G.-D. WANG, X.-H. Zhang, The Schur multiplicative and harmonic convexities of the complete symmetric function, Math. Nachr. 284, 5-6 (2011), 653-663.

[29] Y.-M. CHU, W.-F. XIA, Two sharp inequalities for power mean, geometric mean, and harmonic mean, J. Inequal. Appl. 2009 (2009), Article ID 741923, 6 pages.

[30] Y.-M. CHU, W.-F. XIA, Solution of an open problem for Schur convexity or concavity of the Gini mean values, Sci. China 52A, 10 (2009), 2099-2106.

[31] Y.-M. ChU, W.-F. XIA, X.-H. ZhAng, The Schur concavity, Schur multiplicative and harmonic convexities of the second dual form of the Hamy symmetric function with applications, J. Multivariate Anal. 105 (2012), 412-421.

[32] Y.-M. ChU, W.-F. XIA, T.-H. ZhaO, Schur convexity for a class of symmetric functions, Sci. China Math. 53, 2 (2010), 465-474.

[33] Y.-M. CHU, X.-M. ZHANG, Necessary and sufficient conditions such that extended mean values are Schur-convex or Schur-concave, J. Math. Kyoto Univ. 48, 1 (2008), 229-238.

[34] Y.-M. Chu, X.-M. Zhang, G.-D. WANG, The Schur geometrical convexity of the extended mean values, J. Convex Anal. 15, 4 (2008), 707-718.

[35] Y.-M. ChU, T.-H. ZhaO, Convexity and concavity of the complete elliptic integrals with respect to Lehmer mean, J. Inequal. Appl. 2015 (2015), Article 396, 6 pages.

[36] Y.-M. Chu, T.-H. ZHaO, Concavity of the error function with respect to Hölder means, Math. Inequal. Appl. 19, 2 (2016), 589-595.

[37] V. Heikkala, H. Lindén, M. K. Vamanamurthy, M. Vuorinen, Generalized elliptic integrals and the Legendre $\mathscr{M}$-function, J. Math. Anal. Appl. 338, 1 (2008), 223-243.

[38] T.-R. HuAnG, B.-W. Han, X.-Y. MA, Y.-M. ChU, Optima bounds for the generalized EulerMascheroni constant, J. Inequal. Appl. 2018 (2018), Article 118, 9 pages.

[39] E. A. KARATSUBA, M. VUORINEN, On hypergeometric functions and generalizations of Legendre's relation, J. Math. Anal. Appl. 260, 2 (2001), 623-640.

[40] Y.-M. LI, W.-F. XIA, Y.-M. CHU, X.-H. ZHANG, Optimal lower and upper bounds for the geometric convex combination of the error function, J. Inequal. Appl. 2015 (2015), Article 382, 8 pages.

[41] W.-M. QIAN, Y.-M. CHU, Sharp bounds for a special quasi-arithmetic mean in terms of arithmetic and geometric means with two parameters, J. Inequal. Appl. 2017 (2017), Article 274, 10 pages.

[42] W.-M. QIAn, X.-H. Zhang, Y.-M. ChU, Sharp bounds for the Toader-Qi mean in terms of harmonic and geometric means, J. Math. Inequal. 11, 1 (2017), 121-127. 
[43] S.-L. QIU, M. VuORINen, Landen inequalities for hypergeometric functions, Nagoya Math. J. 154 (1999), 31-56.

[44] S.-L. QIU, M. VUORINEN, Infinite products and the normalized quotients of hypergeometric functions, SIAM J. Math. Anal. 30, 5 (1999), 1057-1075.

[45] S.-L. QIU, M. VuORINEN, Duplication inequalities for the ratios of hypergeometric functions, Forum Math. 12, 1 (2000), 109-133.

[46] S.-L. QIU, M. VuORINEN, Special functions in geometric function theory, In: Handbook of Complex Analysis: geometric function theory, 2, 621-659, Elsevier Sci. B. V., Amsterdam, 2005.

[47] S. Simić, M. VuORInen, Landen inequalities for zero-balanced hypergeometric functions, Abstr. Appl. Anal. 2012 (2012), Article ID 932061, 11 pages.

[48] Y.-Q. Song, M. Adil Khan, S. Zaheer Ullah, Y.-M. Chu, Integral inequalities involving strongly convex functions, J. Funct. Spaces 2018 (2018), Article ID 6595921, 8 pages.

[49] Y.-Q. Song, P.-G. ZHOU, Y.-M. CHU, Inequalities for the Gaussian hypergeometric function, Sci. China Math. 57, 11 (2014), 2369-2380.

[50] M.-K. WANG AND Y.-M. CHU, Asymptotical bounds for complete elliptic integrals of the second kind, J. Math. Anal. Appl. 402, 1 (2013), 119-126.

[51] M.-K. WANG AND Y.-M. CHU, Refinements of transformation inequalities for zero-balanced hypergeometric functions, Acta Math. Sci. 37B, 3 (2017), 607-622.

[52] M.-K. WANG, Y.-M. CHU, Landen inequalities for a class of hypergeometric functions with applications, Math. Inequal. Appl. 21, 2 (2018), 521-537.

[53] M.-K. WANG, Y.-M. CHU AND Y.-P. JiAng, Ramanujan's cubic transformation inequalities for zero-balanced hypergeometric functions, Rocky Mountain J. Math. 46, 2 (2016), 679-691.

[54] M.-K. WAng, Y.-M. ChU, Y.-P. JiAng, S.-L. QIU, Bounds of the perimeter of an ellipse using arithmetic, geometric and harmonic means, Math. Inequal. Appl. 17, 1 (2014), 101-111.

[55] M.-K. WAng, Y.-M. CHU And S.-L. QIU, Some monotonicity properties of generalized elliptic integrals with applications, Math. Inequal. Appl. 16, 3 (2013), 671-677.

[56] M.-K. WANG, Y.-M. CHU AND S.-L. QIU, Sharp bounds for generalized elliptic integrals of the first kind, J. Math. Anal. Appl. 429, 2 (2015), 744-757.

[57] M.-K. WAng, Y.-M. CHU, S.-L. QIU, Y.-P. JiAng, Bounds for the perimeter of an ellipse, J. Approx. Theory 164, 7 (2012), 928-937.

[58] M.-K. WANG, Y.-M. CHU, S.-L. QIU AND Y.-P. JIANG, Convexity of the complete elliptic integrals of the first kind with respect to Hölder means, J. Math. Anal. Appl. 388, 2 (2012), 1141-1146.

[59] M.-K. WANG, Y.-M. CHU, Y.-F. QIU, S.-L. QIU, An optimal power mean inequalities for the complete elliptic integrals, Appl. Math. Lett. 24, 6 (2011), 887-890.

[60] M.-K. WAng, Y.-M. CHU, Y.-Q. Song, Asymptotical formulas for Gaussian and generalized hypergeometric functions, Appl. Math. Comput. 276 (2016), 44-60.

[61] M.-K. WANG, Y.-M. LI, Y.-M. CHU, Inequalities and infinite product formula for Ramanujan generalized modular equation function, Ramanujan J. 46, 1 (2018), 189-200.

[62] H. WANG, W,-M. QIAN, Y.-M. CHU, Optimal bounds for Gaussian arithmetic-geometric mean with applications to complete elliptic integral, J. Funct. Spaces 2016 (2016), Article ID 3698463, 6 pages.

[63] M.-K. WANG, Y.-F. QIU, Y.-M. CHU, Sharp bounds for Seiffert means in terms of Lehmer means, J. Math. Inequal. 4, 4 (2010), 581-586.

[64] M.-K. WANG, S.-L. QIU, Y.-M. CHU, Infinite series formula for Hübner upper bound function with applications to Hersch-Pfluger distortion functions, Math. Inequal. Appl. 21, 3 (2018), 629-648.

[65] M.-K. WANG, S.-L. QIU, Y.-M. CHU, Y.-P. JiAng, Generalized Hersch-Pfluger distortion function and complete elliptic integrals, J. Math. Anal. Appl. 385 (2012), 221-229.

[66] M.-K. WANG, Z.-K. WANG, Y.-M. CHU, An optimal double inequality between geometric and identric means, Appl. Math. Lett. 25 (2012), 471-475.

[67] G.-D. WAng, X.-H. Zhang, Y.-M. CHU, Inequalities for the generalized elliptic integrals and modular functions, J. Math. Anal. Appl. 331, 2 (2007), 1275-1283.

[68] G.-D. WANG, X.-H. ZHANG, Y.-M. CHU, A power mean inequality involving the complete elliptic integrals, Rocky Mountain J. Math. 44, 5 (2014), 1661-1667.

[69] W.-F. XIA, Y.-M. CHU, Optimal inequalities for the convex combination of error function, J. Math. Inequal. 9, 1 (2015), 85-99.

[70] H.-Z. XU, Y.-M. CHU, W.-M. QIAN, Sharp bounds for the Sándor-Yang means in terms of arithmetic and contra-harmonic means, J. Inequal. Appl. 2018 (2018), Article 127, 13 pages. 
[71] ZH.-H YANG, A new way to prove L' Hospitial monotone rules with applications, arXiv:1409.6408v1 [math. CA], available online at http://arxiv.org/pdf/1409.6408v1.pdf.

[72] ZH.-H. YANG, Y.-M. CHU, Asymptotic formulas for gamma function with applications, Appl. Math. Comput. 270 (2015), 665-680.

[73] ZH.-H. YANG, Y.-M. CHU, A monotonicity propertry involving the generalized elliptic integral of the first kind, Math. Inequal. Appl. 20, 3 (2017), 729-735.

[74] ZH.-H. YANG, Y.-M. CHU, M.-K. WANG, Monotonicity criterion for the quotient of power series with applications, J. Math. Anal. Appl. 428, 1 (2015), 587-604.

[75] ZH.-H. YANG, Y.-M. ChU, W. ZHANG, Accurate approximations for the complete elliptic integral of the second kind, J. Math. Anal. Appl. 438, 2 (2016), 875-888.

[76] ZH.-H. YAng, Y.-M. ChU, W. ZHANG, Monotonicity of the ratio for the complete elliptic integral and Stolarsky mean, J. Inequal. Appl. 2016 (2016), Article 176, 10 pages.

[77] ZH.-H. YANG, Y.-M. CHU, W. ZHANG, Sharp Stolarsky mean bounds for the complete elliptic integral of the second kind, J. Nonlinear Sci. Appl. 10, 3 (2017), 929-936.

[78] ZH.-H. YANG, W.-M. QiAn, Y.-M. ChU, W. ZhANG, Monotonicity rule for the quotient of two functions and its application, J. Inequal. Appl. 2017 (2017), Article 106, 13 pages.

[79] ZH.-H. YANG, W.-M. QIAN, Y.-M. CHU, W. ZHANG, On rational bounds for the gamma function, J. Inequal. Appl., 2017 (2017), Article 210, 17 pages.

[80] ZH.-H. YANG, W.-M. QIAN, Y.-M. ChU, W. ZHANG, On approximating the arithmetic-geometric mean and complete elliptic integral of the first kind, J. Math. Anal. Appl. 462, 2 (2018), 1714-1726.

[81] ZH.-H. YANG, W.-M. QIAN, Y.-M. CHU, W. ZHANG, On approximating the error function, Math. Inequal. Appl. 21, 2 (2018), 469-479.

[82] ZH.-H. YANG, Y.-Q. Song, Y.-M. ChU, Sharp bounds for the arithmetic-geometric mean, J. Inequal. Appl. 2014 (2014), Article 192, 13 pages.

[83] ZH.-H. YANG, W. ZHANG, Y.-M. CHU, Monotonicity and inequalities involving the incomplete gamma function, J. Inequal. Appl. 2016 (2016), Article 221, 10 pages.

[84] ZH.-H. YANG, W. ZHANG, Y.-M. CHU, Monotonicity of the incomplete gamma function with applications, J. Inequal. Appl. 2016 (2016), Article 251, 10 pages.

[85] ZH.-H. YANG, W. ZHANG, Y.-M. ChU, Sharp Gautschi inequality for parameter $0<p<1$ with applications, Math. Inequal. Appl. 20, 4 (2017), 1107-1120.

[86] X.-H. ZhANG, Solution to a conjecture on the Legendre $M$-function with an application to the generalized modulus, J. Math. Anal. Appl. 431, 2 (2015), 1190-1196.

[87] X.-M. Zhang, Y.-M. CHU, A double inequality for gamma function, J. Inequal. Appl. 2009 (2009), Article ID 503782, 7 pages.

[88] X.-H. Zhang, G.-D. Wang, Y.-M. Chu, Convexity with respect to Hölder mean involving zerobalanced hypergeometric functions, J. Math. Anal. Appl. 353, 1 (2009), 256-259.

[89] X.-H.Zhang, G.-D. WAnG, Y.-M. ChU, Remarks on generalized elliptic integrals, Proc. Roy. Soc. Edinburgh 139A, 2 (2009), 417-426.

[90] T.-H. ZHAO, Y.-M. CHU, A class of logarithmically completely monotonic functions associated with gamma function, J. Inequal. Appl. 2010 (2010), Article ID 392431, 11 pages.

[91] T.-H. ZhAO, Y.-M. CHU, Y.-P. JIANG, Monotonic and logarithmically convex properties of a function involving gamma functions, J. Inequal. Appl. 2009 (2009), Article ID 728612, 13 pages.

[92] T.-H. ZHAO, Y.-M. CHU, H. WANG, Logarithmically complete monotonicity properties relating to the gamma function, Abstr. Appl. Anal. 2011 (2011), Article ID 896483, 13 pages. 